\title{
FROM ACCOUNTING PROFESSIONAL TO TEACHING CAREER: A STUDY ON THE MOTIVATIONAL FACTORS FOR THE TRANSITION
}

\section{DE PROFISSIONAL CONTÁBIL À CARREIRA DOCENTE: UM ESTUDO SOBRE OS FATORES MOTIVACIONAIS PARA A TRANSIÇÃO}

\section{DE PROFESIONAL CONTABLE A LA CARRERA DOCENTE: UN ESTUDIO SOBRE LOS FACTORES MOTIVACIONALES PARA LA TRANSICIÓN}

Recebido em: 18-04-2019

Avaliado em: 25-07-2020

Reformulado em: 10-08-2020

Aceito para publicação em: 23-09-2020

Publicado em: 31-12-2020

Editor Responsável: Moacir M. Rodrigues Jr. \& Marcia

Zanievicz Silva
Carla Milena Gonçalves Fernandes ${ }^{1}$

Débora Gomes de Gomes ${ }^{2}$

Marcos Antônio de Souza ${ }^{3}$

\section{ABSTRACT}

The aim of the study is to know the predominant motivational factors in the dismissal of an accounting profession and the insertion in the teaching career of professors of the Accounting Sciences Course of Brazilian Public Federal Universities. This was a descriptive and quantitative research, with the participation of 37 teachers. The two sets of assertions (professional termination and insertion in the teaching career) were correlational to verify the adjustment of the data for later application of the factorial analysis, in order to answer the study's objective. It can be noticed that the motivations present in the first set (professional termination) belong to the introjected and identified regulations, besides the appearance of demotivation as one of the factors. Such demotivation reflects the discontent with the development of the professional career. In the second set (insertion in the teaching career), introjected, external and intrinsic motivations were found to be related to public employment stability, remuneration, relevance, pleasure and social recognition of the activity. The results obtained were considered satisfactory since they provide a visualization of the stimuli before and after the insertion in the teaching career as well as the motivating factors for the permanence in this career.

Keywords: Accounting; Teaching; Motivation; Public Federal Universities.

\footnotetext{
1 Bacharel em Administração pela Universidade Federal do Rio Grande (FURG); Mestranda em Contabilidade pela Universidade Federal do Rio Grande (FURG); Endereço: Campus Carreiros. Avenida Itália, Km 8 - Bairro Carreiros, Rio Grande - RS - Brasil, CEP: 96203-900; E-mail: carlafernandes@ furg.br; Telefone: +55 (53) 991634070

2 Bacharel em Administração pela Universidade Federal do Rio Grande (FURG); Mestranda em Contabilidade pela Universidade Federal do Rio Grande (FURG); Endereço: Campus Carreiros. Avenida Itália, Km 8 - Bairro Carreiros, Rio Grande - RS - Brasil, CEP: 96203-900; E-mail: carlafernandes@ furg.br; Telefone: +55 (53) 991634070

3 Bacharel em Administração pela Universidade Federal do Rio Grande (FURG); Mestranda em Contabilidade pela Universidade Federal do Rio Grande (FURG); Endereço: Campus Carreiros. Avenida Itália, Km 8 - Bairro Carreiros, Rio Grande - RS - Brasil, CEP: 96203-900; E-mail: carlafernandes@ furg.br; Telefone: +55 (53) 991634070
} 


\section{RESUMO}

O objetivo do estudo é conhecer os fatores motivacionais predominantes no desligamento de uma profissão contábil e a inserção na carreira docente, de professores do Curso de Ciências Contábeis de Universidades Públicas Federais brasileiras. Trata-se de uma pesquisa descritiva e quantitativa, que contou com a participação de 37 docentes. Os dois conjuntos de assertivas (desligamento profissional e inserção na docência) foram correlacionais para verificar o ajuste dos dados, para posterior aplicação da análise fatorial, com o intuito de responder ao objetivo do estudo. Pode-se perceber que as motivações presentes no primeiro conjunto (desligamento profissional) são pertencentes as regulações introjetadas e identificadas além do aparecimento da desmotivação como um dos fatores. Tal desmotivação reflete o descontentamento com o desenvolvimento da carreira profissional. No segundo conjunto (inserção na docência) foram encontradas as motivações do tipo introjetada, externa e intrínseca, relacionadas à estabilidade no emprego público, remuneração, relevância, prazer e reconhecimento social da atividade. Os resultados obtidos foram considerados satisfatórios, pois fornecem uma visualização dos estímulos antes e após a inserção na carreira docente bem como os fatores motivadores para a permanência nessa carreira.

Palavras-chave: Contabilidade; Docência; Motivação; Universidades Públicas Federais.

\section{RESUMEN}

El objetivo del estudio es conocer los factores motivacionales predominantes en el cierre de una profesión contable y la inserción en la carrera docente, de profesores del Curso de Ciencias Contables de Universidades Públicas Federales brasileñas. Se trata de una investigación descriptiva y cuantitativa, que contó con la participación de 37 docentes. Los dos conjuntos de asertivas (desligamiento profesional e inserción en la docencia) fueron correlacionales para verificar el ajuste de los datos, para posterior aplicación del análisis factorial, con la intención de responder al objetivo del estudio. Se puede percibir que las motivaciones presentes en el primer conjunto (desligamiento profesional) son pertenecientes a las regulaciones introyectadas e identificadas además de la aparición de la desmotivación como uno de los factores. Tal desmotivación refleja el descontento con el desarrollo de la carrera profesional. En el segundo conjunto (inserción en la docencia) se encontraron las motivaciones del tipo introyectada, externa e intrínseca, relacionadas a la estabilidad en el empleo público, remuneración, relevancia, placer y reconocimiento social de la actividad. Los resultados obtenidos fueron considerados satisfactorios, pues proporcionan una visualización de los estímulos antes y después de la inserción en la carrera docente así como los factores motivadores para la permanencia en esa carrera.

Palabras-clave: Contabilidad; Enseñanza; Motivación; Universidades Públicas Federales.

\section{INTRODUCTION}

In an increasingly dynamic environment, the need for committed professionals at the work environment is relevant. In this sense, the accounting professional and his vocational skills are included, such as the interpersonal capacity for problem-solving (Daniels \& Davids, 2019; Klaeijsen, Vermeulen \& Martens, 2017), as well as an analytical aptitude for communication (Schmutte, 1998).

The choice for a career permeates some specifications such as personal characteristics and the environment, which can be an influencer of the option, for example the relationship with co-workers, as well as the working conditions offered (Abdelmoula \& Boudabbous, 2019). In addition, as far as the choice for an accounting career is concerned, it occurs in the first two years of college, aligning itself after graduation toward the area of greatest interest (Myburgh, 2005). 
Therefore, when there is a coherent management of professional choices, they become a source of personal fulfillment, and the sense of well-being emerges proportionately when there is an increase in the capacity to carry out projects (Silva, 2016). Thus, there are several factors that motivate people to enter a teaching career, such as social and cultural aspects, for instance. In addition, there are three types of motivation present in the literature: intrinsic, extrinsic and altruistic factors (Han \& Yin, 2016).

The intrinsic factors are related to satisfaction through the work to be performed, the possibility of externalizing creativity, besides the opportunity to be intellectually stimulated (Felton, Dimnik \& Northey, 1995). As for extrinsic factors, Ryan and Deci (2000) argue four classifications: external regulation (involves rewards), introjected regulation (anxiety about not achieving something desired), identified regulation (recognition of a new career), and integrated regulation (connections of behavioral elements and goals achieved).

Accordingly, with respect to the multifaceted aspect of Accounting, and in the face of external and internal motivations, which directs the professional to the field of greatest interest, there are some characteristics and/or aspects that can ratify and lead this professional towards areas that can materialize their aptitudes and, consequently, the stimulus in the achievement of his or her objectives, for example, organizational aspects (organization structure, working conditions, etc.) (Klaeijsen et al., 2017).

According to a systematic search carried out in the period 2008-2017 in the portals of the Coordination of Improvement of Brazilian Higher Education Personnel (CAPES), the Integrated System of Libraries of the University of São Paulo (SIBI-USP) and the Journal of Education and Research in Accounting (REPeC), 59 related studies were found related to, respectively, motivation, professional teaching, and Accounting.

Nadim, Chaudhry, Kalyar and Riaz (2012) and Gagné et al. (2010) point out that one of the main topics addressed in behavioral studies mentions motivation, however, there are still few studies inherent to the reasons for the insertion in the teaching career. In addition, Abdelmoula and Boudabbous (2019) and Daniels and Davids (2019) reiterate that the incipient research on aspects that motivate accounting professionals to express their concerns becomes a gap to be filled, as the conduct of such studies can imply better perceptions as to the determinant aspects that make such a professional remain in the activities for which he has chosen or opts for another career.

In this context, the guiding question for this study is: What are the motivational factors that determine the transition from accounting professional to a teaching career, with exclusive dedication, in the Brazilian public federal institutions? In view of the indicated problem, the aim is to investigate the predominant motivational factors for the transition of accounting professionals to the teaching career of professors of Accounting Sciences in Brazilian Federal Universities at a national level.

In the face of the various work possibilities for the accounting professional, as, for example: in companies (internal auditor, fiscal accountant, administrative positions), autonomous professionals (independent auditor, accounting expert), public agency workers (public accountant, tax assessor) and in teaching (professor, researcher), a study about career change becomes an interesting topic (Fonseca, Taroco, Nazareth \& Ferreira, 2014). Han and Yin (2016) and Klaeijsen et al. (2017) argue that identifying motivational factors in relation to teachers are relevant since motivated teachers drive their students in a favorable way. Studies with this focus provide an interesting profile about the influences, interests, motives, and aspirations of professionals who opt for entering the teaching profession (Richardson \& Watt, 2005). Thus, in view of the foregoing, teachers from public institutions whose premise is exclusive dedication to work were taken as the study boundary.

This work is structured in five main sections: I) study contextualization and problematization; II) literature review; III) methodological procedures; IV) result analysis; and finally V) final considerations and references used in this paper. 


\section{ACCOUNTING PROFESSIONALS AND MOTIVATIONAL FACTORS}

Accounting is formed by a group of techniques that serve to register and to demonstrate results in an impartial way (Roberts, 1991). Thus, the role of the accountant is to transmit data in a practical way in order to originate information that will be used by its users for decision making. The accounting professional working in a private company must present a dynamic organizational behavior in order to provide a lower chance of conflict within the work environment (Abdelmoula \& Boudabbous, 2019).

Meanwhile this professional, when involved in the public sphere, positions itself in a way that aligns itself with the stakeholders, that is, he or she becomes a vehicle for communication in order to elaborate and provide useful information for society (Lehman, 2001). Given the innumerable possibilities of career directions that accounting professionals can choose from, such as acting autonomously or in private and public sectors (Fonseca et al., 2014), the process of choosing a professional career is given through a reflexive conscience determined by prior knowledge of the profession he or she pursues, as well as experiences provided during some form of professional practice (Tuckman, 1974).

For such, in the period between choice/professional development, there are some factors such as preferences, behaviors (attitudes, opinions), references, aspirations, motives, needs, and abilities The terms cited can be subdivided into three groups: (a) what causes stimulation (motives, needs and predisposition); (b) what causes direction, or targeting (preferences, behaviors, references and values); and (c) what causes inclination (aspirations and abilities) (Tuckman, 1974). Thus, the reasons why professionals working in the accounting career choose to dedicate themselves to a teaching career include not only the search for stability in a public career but also the motivations that guide such a profession, such as: the commitment of acting teaching students the relevance of the accounting profession (Bruinsma \& Jansen, 2010).

By inserting the word motivation, which comes from Latin and means 'to move', it indicates that it is a process that occurs through some stimulus and/or incentive. Thus, the term motivation means to have an objective and, from it, to make a decision, considering that each individual has a predisposition for the development of some motivational forces such as, for example, the way in which he or she understands his or her work and their life (Silva, 2016).

In this sense, it can be said that motivation is a continuum of efforts, through motivational elements that direct people towards achieving their goals (Klaeijsen et al., 2017). According to Law (2010), a subjective precept can be mentioned by means of a sum of evaluations regarding the perceived individual conceptions versus the motivational elements existing at the time of the decision.

Accordingly, research related to motivation and teaching that may allow a glance at the reasons that lead a professional into the Academy was boosted and expanded through studies starting from the 1990s, whose initial focus was the sociocultural context in the which this professional would be involved (Han \& Yin, 2016).

In addition, external stimuli tend to intervene in behavior, causing transformations in people's belief structures (Law, 2010), as well as internal stimuli, which act as a force driving the individual toward the established goal (Pelletier et al., 1995). Thus, a survey of the extrinsic, intrinsic and motivational factors, through means of a taxonomy, lead to a better visualization and understanding of the proposed subject (Klaeijsen et al., 2017).

Ryan and Deci (2000) express a taxonomy of human motivation, explained below in Figure 1, which was classified into six motivational categories: demotivation, extrinsic motivation (external, introjected, identified and integrated) and intrinsic motivation. From the categories produced by the authors, one can visualize the different dimensions of existing motivations, which can act positively or negatively in the career choice.

\section{Figure 1. Taxonomy of Human Motivation}




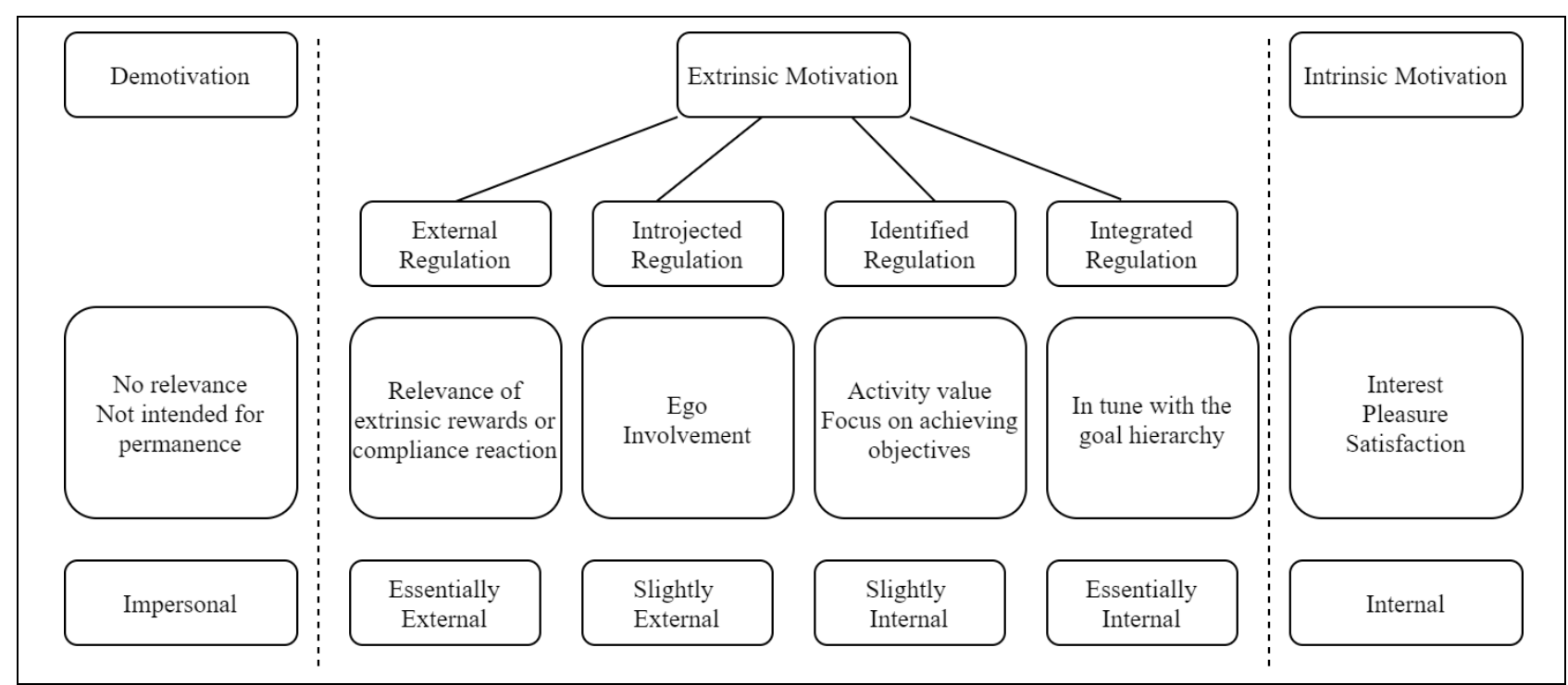

Source: Adapted from Ryan and Deci (2000, p. 61)

Figure 1, developed by the cited authors, expresses from left to right a linearity concerning the relations between the motivations and the components that generate the behavior, inherent to the various reactions (external and internal). Thus, in an attempt to understand this proposed study, it is necessary to clarify the categories (demotivation, extrinsic motivation, and intrinsic motivation).

\subsection{Demotivation}

Demotivation, as the term itself suggests, involves a lack of motivation in the development of some activity (Ryan \& Deci, 2000). According to Markland and Tobin (2004), amotivation or demotivation is characterized as a non-auto determined regulation, that is, it permeates the absence of any intentionality of involvement.

In addition, amotivation occurs when there is a lack of contingency between the individual's behavior and his or her results, that is, there is no purpose or expectation that motivates him to remain in the performance of the activity (Vallerand \& Bissonnette, 1992). Kiziltepe (2008) adds that the demotivation involves the disinterest for something or some activity that no longer provides a sense of involvement on the part of the individual, thus reflecting in low energy to continue performing the task or even the permanence in the professional career.

\subsection{Extrinsic Motivation}

Extrinsic motivation is characterized by actions (behaviors) whose circumstances are external, such as receiving rewards (Pelletier et al., 1995). This motivation is associated not only with the reward aspect, for there are other types that compose this extrinsic motivation, such as impositions, sanctions, among others (Ryan \& Deci, 2000).

The individual is extrinsically motivated when his actions are directed at a certain task in order to obtain something external. Extrinsic motivation may be linked to aspects dependent on professional occupation, eg. pay for performance, or may be tied to an external motive, which serves as a control for the task to be performed satisfactorily, such as praise and promise of rewards (Amabile, 1993). In sum, extrinsic motivation is related to a construct of activities with the intention of reaching a result (Ryan \& Deci, 2000).

Thus, it is noted that extrinsic motivation encompasses a complex variety of actions that interconnects with the purposes inherent to personal interest (pleasure) and whose goal is the achievement of results (Vallerand \& Bissonnette, 1992). This motivation can be seen in a continuum, that is, under four subcategories or regulations: external regulation, introjected regulation, identified regulation and integrated regulation (Ryan \& Deci, 2000). 
External Regulation represents an externally regulated action since the resultant of the motivation to reach the goal is linked to forms of rewards (Vallerand \& Bissonnette, 1992). Deci, Vallerand, Pelletier and Ryan (1991) refer to external regulation as actions that are external to the individual - that is, there are rewards and ways of punishment that lead people to perform certain tasks. In this way, this regulation can be considered a self-determined motivation, but at an early stage. The most negative motivations are more focused on external regulation and amotivation (Vallerand \& Bissonnette, 1992).

The Introjected Regulation is represented by people who seek ways to internalize their motives through attitudes - that is, this motivation is directly related to external contingencies, to actions in search of an end result which, among one of the reasons, is related to the involvement of the ego (Vallerand \& Bissonnette, 1992). It also involves self-determined behavior, since it presents itself in a slightly external way, encompassing artifices such as the requirement for punctuality (Deci et al., 1991).

The Identified Regulation represents the effort that the individual visualizes in order to achieve his or her objective, serving to improve his or her knowledge and/or ability (Vallerand \& Bissonnette, 1992). According to Deci et al. (1991), the Identified Regulation is related to the task performed, through voluntary behaviors, and as such, there is an identification between the person and the task that enables a peaceful involvement. For Vallerand (1993) it is fundamental that the individual is selfdeterminedly motivated in some way so that he or she can perceive themselves to be inserted in the Identified or Integrated Regulation and even in Intrinsic Motivation. For Amabile, Hiell, Hennessey and Tighe (1994) it is the intrinsic motivation that has the most satisfactory aspects.

The Integrated Regulation represents the motivation that is totally linked to behavior, towards the accomplishment of something through a strong will and actions that are carried out with the intention of reaching a goal. In other words, in the integrated regulation, there is a syntony between the actions (behavior) and the achieved result (Vallerand \& Bissonnette, 1992). This regulation is the most evolved form of external motivation because it involves harmony between the needs and values of the individual and the desired professional career.

In this way, one can consider it to be totally self-determined, for there is a balance between the behavior and the goals. In addition, Integrated Regulation is also associated with Intrinsic Motivation, since both express forms of self-regulation. Their difference consists in the fact that Integrated Regulation is related to activity as an important factor to achieve the result, while Intrinsic Motivation permeates the interest and satisfaction for the activity in itself (Deci et al., 1991).

\subsection{Intrinsic Motivation}

Intrinsic Motivation is characterized by behaviors that are not tied to rewards - that is, they are activities that, when performed, will provide contentment (pleasure) (Vallerand \& Bissonnette, 1992). In this way, the study about intrinsic motivation becomes relevant because of its direct influence on the quality and creativity of individuals, who perform their activities because of the emotional nature they provide. Therefore, this motivation permeates the search for practices that cause pleasure and interest (Ryan \& Deci, 2000).

In short, intrinsic motivation is related to an internal structure, inherent in the individual's personality. However, this type is the most common regarding the profession when it involves teaching as a career, permeating motives such as interest, enthusiasm and encouragement to creative ideas (Klaeijsen et al., 2017).

For Amabile (1993) this motivation can also be visualized when the individual is instigated to a new professional challenge, generating a feeling regarding the activity. Thus, it is in the Intrinsic Motivation that one visualizes the most positive consequences since the determining factor focuses on the activity itself and not on the final result (Abdelmoula \& Boudabbous, 2019). 


\subsection{Previous Studies}

The first stage of the study consisted of a systematic search, in the period of 10 years (20082017), in papers belonging to the platforms: CAPES, SIBI (USP) and REPeC, resulting in 59 publications related to, respectively, motivation, teaching, and accounting. In the sequence, a triage was carried out, of which six papers were selected as the most relevant for the current topic. The procedures for choosing the articles consisted of reading the titles, abstracts, and keywords that were linked to the proposed study.

Miranda, Leal and Medeiros analysed the results of the implementation of a project called Interdisciplinary Practices in a superior education course in Accounting Sciences. From the study, the authors inferred the need for preparation by the teachers regarding the concept of interdisciplinarity. In addition, the authors identified the lack of effective actions for the training of teaching professionals.

Valenzuela, Valenzuela, Silva-Peña, Nocetti and Gandarillas (2015) studied theoretical schemes relating them to the motivational formation of future educators. Thus, in their results, they demonstrated the relevance of motivation for this professional, because it is not enough to require teachers to motivate their students if these professionals are lacking the necessary skills to do so. Therefore, they discussed the intrinsic and extrinsic motivations, which are important elements to be perceived in order to later be able to operationalize them in the teachers.

Accordingly, the study by Araújo, Lima, Oliveira and Miranda (2015) resulted in a mapping that evidenced the central problems faced by higher education teachers in Accounting when entering their careers and later on. Thus, the answers uncovered revealed that the most critical stage is related to entering the teaching career due to lack of pedagogical training among teachers in the Accounting area, as well as another result revealed that there is a significant number of activities that this teacher needs to engage in.

In the study by Han and Yin (2016), the authors aimed to present a literature review about the motivational factors of teachers from the perspective of five research axes: influence of the factors that motivate such professional to develop; motivation of teachers who teach various subjects; influence of student motivation; teaching and teaching learning. The results signaled that there is a need to formulate strategies that motivate not only the student, but also the teacher, as this is one of the pillars that promote improvements in education.

Davoglio, Spagnolo and Santos (2017) carried out research that sought to explain the aspects that motivate higher education teachers to remain in teaching. The conclusions obtained indicate that one of the main motivating elements refers to intrinsic aspects such as pleasure and satisfaction in practicing the profession, as well as the relationship with students beyond the academic environment. Regarding the study by Klaeijsen, Vermeulen and Martens (2017), the objective consisted, from the Theory of Self-Determination, to demonstrate which motivational processes are interconnected to the innovative behavior of the teacher. The results based on the method of structural equations showed that the intrinsic motivation is closely related to the satisfaction of psychological needs. In addition, another point of emphasis in the study was the influence that the constructs motivation and selfefficacy had on the construct innovative behavior of teachers.

Other studies, for example, by Abdelmoula and Boudabbous (2019) sought to analyze the satisfaction of Accountants in the course of their professional activity in Tunisia. The authors identified, through the factor analysis technique, that both intrinsic and extrinsic motivational factors have a significant influence on the satisfaction of exercising the accounting profession. Furthermore, the results also signaled that the most prevalent intrinsic factors for job satisfaction are: promotion, achievement, work and professional growth. Regarding extrinsic factors, there is a predominance in the satisfaction of accountants when four aspects are improved: professional relationship (senior management and co-workers), salary, company policy, as well as conditions for improvement in the work environment. 
In addition, the research by Daniels and Davids (2019) sought to analyze the satisfaction of professionals and / or future accounting professionals when they experience the profession during the academy and after graduation. The results obtained showed that the non-professionals showed higher levels of satisfaction than those already graduated. In addition, the factors that most predominated, from the perspective of not yet Accountants, as "ideal job" were: remuneration, professional growth, working hours, as well as the challenges of the profession.

\section{METHODOLOGICAL PROCEDURES}

The study population consisted of acting teachers of the Accounting Sciences course of Brazilian Federal Universities (BFU). To do so, a search was conducted on the Ministry of Education's electronic portal, in the period from June 2018, in order to identify the institutions and their respective coordinators. There were 39 federal public universities, nationwide, that hold an Accounting Sciences Course.

In addition, further searches were carried out in the institutions' websites to identify the emails addresses of the respective course coordinators. After these identifications, the statements were inserted in the Google Forms platform. It should be mentioned that the sample was gathered by convenience since it focused on all professionals who had an employment relationship (private company and/or autonomous) and who decided to follow their profession into the teaching career in public institutions in particular, which have as criterion dedication to academic work. It should be noted that the instrument was validated, that is, from the translation of it into Portuguese, there were eight people who were available to answer the instrument and, thus, suggest improvements regarding the adequacy of the statements. It should be noted that among the respondents, four are professors and five are graduate students, both in the area of Accounting.

The study consisted of the search for BFU (Brazilian Federal Universities) teachers, who, for the purpose of the analysis, necessarily exercised activities previous to teaching related to business accounting. Of the 39 BFUs located, there were a total of 13 participating universities, them being: Federal University of Rio Grande (FURG), Federal University of Campina Grande (UFCG), Federal University of Espírito Santo (UFES), Fluminense Federal University (UFF), Federal University of Goiás (UFG), Federal University of Grande Dourados (UFGD), Federal University of Mato Grosso do Sul (UFMS), Federal University of Pará (UFPA), Federal University of Pernambuco (UFPE), Federal University of Paraná (UFPR), Federal University of Rio Grande do Norte (UFRN), Rural Federal University of Rio de Janeiro (UFRRJ) and Federal Technological University of Paraná (UTFPR).

In order to respond to the research problem, the data collection instrument, adapted from Richardson and Watt (2005; 2007), was composed of a questionnaire containing 29 objective assertions distributed on a Likert scale, whose extremes were: (1) totally disagree to (5) totally agree, plus two questions for the verification of some aspects regarding the professional, such as the age group and time of acting as a teacher. Finally, there is an open question to enable the teacher to explain the reasons that led to his or her transition. There are, thus, 32 questions related to motivations for a career change. It should be noted that the 29 assertions were divided into two blocks, as follows: (a) assessment of reasons for dismissal as a private and/or self-employed professional; (b) assessment of the reasons for the choice for the teaching career and its permanence.

The data analysis was based on exploratory factor analysis, which provides, from a set of variables, a smaller grouping of uncorrelated factors, that can facilitate the understanding of the relations and offer a better explanation of the phenomenon, verifying the more impactful components (Corrar, Paulo, Dias \& Rodrigues, 2017). For this quantitative process, the Statistical Package for the Social Sciences (SPSS) software was used. 


\section{DATA ANALYSIS AND RESULTS}

Of the 39 BFUs participants, a total of 37 teachers participated in the research. Nine respondents were excluded because they had not had professional functions before joining the teaching career. Therefore, the final sample had the assertions answered by 28 professionals.

From the use of the SPSS software, the KMO (Kaiser-Lawyer-Olkin) measure was initially used to show the adequacy (adjustment) of the variables for the use of the factorial analysis, whose variables' value necessarily need to be higher than 0,50 , indicating the acceptance of the statistical analysis (Hair, Black, Babin, Anderson \& Tatham, 2009). Bartlett's test of sphericity represents the level of significance of the variables. That means that the closer to zero $(0.000)$, the greater the adequacy to the data set (Corrar et al., 2017).

The factor analysis was elaborated based on the 29 asserted answers, so that at the end of the analysis it was possible to identify which of the six categories, expressed by Ryan and Deci (2000), would be more evident. This enables the verification of the latent factors inherent to leaving the professional career and which are the most significant for entering and remaining in the teaching profession. Two factorial analyses were carried out: the first one for the set of 12 assertions regarding the previous career termination; the second for the set of variables on the transition to teaching, arranged in 17 assertions.

\subsection{Factorial Analysis for Leaving the Accounting Profession in a Private Company and/or Autonomously}

12 assertions were inserted in this topic, adapted from Richardson and Watt $(2005,2007)$, that led the accounting professional to quit the activity in a private organization, or even to cease their autonomous activities. They were answered by the 28 participating teachers who had practiced their professional careers before joining the teaching profession. To visualize the adequacy of the data found, Table 1 expresses the values obtained in Bartlett's test of sphericity, as well as the KMO measurement.

Table 1 - Bartlett Test and KMO

\begin{tabular}{lrr}
\hline Kaiser-Meyer-Olkin & & 0,592 \\
\hline Bartlett's Test of Sphericity & Approximate chi-square & 111,231 \\
\hline & df & 66 \\
\hline & Significance & 0.000 \\
\hline
\end{tabular}

Source: This table shows the values for the KMO and Bartlett's test of sphericity

Table 1 shows that the KMO value (0.592) can be considered acceptable (Hair et al., 2009), meaning that there are conditions of a factorial analysis in this model. In addition, the value found in the Bartlett test (0.000) satisfies the acceptable range, ie, there is an adjustment to the data set (Corrar et al., 2017). As to what assertions have a power of explanation in the model, Table 2 shows the values of the variances for each of them.

The results of Table 2 identify that out of the 12 assertions answered, five are the ones that best explain (77.48\%) the career termination (private or autonomous) before the beginning of the teaching career. For this end, a principal component analysis (PCA) was used, since it is a method that seeks to explain the minimum number of factors that can answer by the maximum variance of the data. Table 3 comprises the data adjustments due to an orthogonal rotation performed by the varimax method, which serves to identify the variables that are composed of a single factor (Corrar et al., 2017). 
FROM ACCOUNTING PROFESSIONAL TO TEACHING CAREER: A STUDY ON THE MOTIVATIONAL FACTORS FOR THE TRANSITION

Table 2 - Total Variance Explained

\begin{tabular}{|c|c|c|c|c|c|c|c|c|c|}
\hline \multicolumn{4}{|c|}{ Initial $P$ values } & \multicolumn{3}{|c|}{ Sum of extraction of square loads } & \multicolumn{3}{|c|}{ Sum of rotations of square loads } \\
\hline Comp. & Total & $\%$ var. & $\%$ acum. & Total & $\%$ var. & $\%$ acum. & Total & $\%$ var. & $\%$ acum. \\
\hline 1 & 3,386 & 28,218 & 28,218 & 3,386 & 28,218 & 28,218 & 2,735 & 22,793 & 22,793 \\
\hline 2 & 2,323 & 19,360 & 47,579 & 2,323 & 19,360 & 47,579 & 1,953 & 16,275 & 39,068 \\
\hline 3 & 1,414 & 11,786 & 59,365 & 1,414 & 11,786 & 59,365 & 1,751 & 14,589 & 53,656 \\
\hline 4 & 1,102 & 9,184 & 68,549 & 1,102 & 9,184 & 68,549 & 1,472 & 12,268 & 65,925 \\
\hline 5 & 1,072 & 8,933 & 77,482 & 1,072 & 8,933 & 77,482 & 1,387 & 11,557 & 77,482 \\
\hline 6 & 0,727 & 6,062 & 83,543 & & & & & & \\
\hline 7 & 0,632 & 5,266 & 88,810 & & & & & & \\
\hline 8 & 0,409 & 3,408 & 92,218 & & & & & & \\
\hline 9 & 0,295 & 2,460 & 94,678 & & & & & & \\
\hline 10 & 0,253 & 2,106 & 96,784 & & & & & & \\
\hline 11 & 0,230 & 1,913 & 98,697 & & & & & & \\
\hline 12 & 0,156 & 1,303 & 100,000 & & & & & & \\
\hline
\end{tabular}

Source: Extraction method: principal component analysis

Table 3 - Component's Rotation Matrix

\begin{tabular}{lccccc}
\hline \multicolumn{1}{c}{ Assertions } & \multicolumn{3}{c}{ Component } \\
\hline & 1 & 2 & 3 & 4 & 5 \\
\hline I have the qualities to be a good teacher & $\mathbf{0 , 7 1 1}$ & $-0,166$ & 0,323 & $-0,260$ & 0,021 \\
I have good teaching skills & $\mathbf{0 , 7 6 8}$ & 0,131 & 0,288 & 0,303 & 0,074 \\
Teaching is a career that makes me feel important & 0,229 & $\mathbf{0 , 8 2 0}$ & 0,152 & $-0,168$ & $-0,020$ \\
Opportunity of fitting vacation time with family vacation & 0,055 & 0,494 & $-0,684$ & $-0,068$ & 0,340 \\
A teaching qualification is recognized everywhere & 0,080 & $\mathbf{0 , 8 1 8}$ & $-0,065$ & $-0,081$ & $-0,130$ \\
A teaching job allows me to choose where I want to live & $\mathbf{0 , 8 1 8}$ & 0,186 & $-0,239$ & $-0,107$ & 0,004 \\
Teaching allows me to influence the next generation & $-0,080$ & $-0,291$ & 0,288 & 0,337 & 0,640 \\
I was dissatisfied with my previous career & 0,226 & 0,009 & $-0,096$ & $-0,169$ & $\mathbf{0 , 8 7 3}$ \\
I can make a greater contribution to society as a teacher & 0,078 & 0,218 & $\mathbf{0 , 8 5 1}$ & 0,134 & 0,171 \\
I thought carefully before entering the teaching career & 0,166 & $-0,154$ & 0,292 & $\mathbf{0 , 8 3 4}$ & 0,025 \\
I always wanted to be a teacher & $\mathbf{0 , 7 5 9}$ & 0,256 & $-0,102$ & 0,089 & 0,179 \\
My family always thought I had vocation for teaching & 0,492 & 0,257 & 0,314 & $-0,631$ & 0,120 \\
\hline
\end{tabular}

Source: Extraction method: principal component analysis; Rotation Method: Varimax with Kaizer normalization

Table 3 expresses the rotation of the components and causes the variables to be classified more precisely in each of the latent factors. Taking into account that values close to 1 or -1 , respectively, mean high positive correlation and high negative correlation (Corrar et al., 2017). In this study, the factors assumed as relevant were considered above +0.7 or -0.7 . Thus, it can be summarized as presented below.

Factor 1: a teaching job allows me to choose where I want to live; I have good teaching skills; I always wanted to be a teacher; I have the qualities to be a good teacher. Factor 2: teaching is a career that makes me feel important; a teaching qualification is recognized everywhere. Factor 3: I can make a greater contribution to society as a teacher; Factor 4: I thought carefully before entering the teaching career. Factor 5: I was dissatisfied with my previous career.

From these data, it is necessary to name factors to define the relationship between the variables, in order to interpret the results. Thus, the naming of factors occurs through the 
understanding of factorial loads - that is, the values with higher loads influence the name to be chosen (Hair et al., 2009): Factor 1: skills and teaching qualities; Factor 2: recognition in the professional career; Factor 3: contribution to society; Factor 4: opting for the teaching career; Factor 5: dissatisfaction with previous career.

Relating to factor 1 (skills and teaching qualities) and factor 4 (choice by the teacher), they can be classified as extrinsic motivation, with an emphasis on the identified regulation, since, according to Vallerand and Bissonnette (1992), in this regulation are behaviors that are perceived by the individual as something that was chosen by him or herself. That means that there is an identification between the person and the task to be performed. Therefore, the behavior can also be understood as autonomous or self-determined, due to the perception of the professional's sense of choice (Deci et al., 1991).

Klaeijsen et al. (2017) argue that the quality of teaching practice is closely related to the way he understands his profession, for example, something capable of improving processes, in this case, educational ones. While this professional perceives himself as a subject capable of stimulating and stimulating other individuals, the tendency is for there to be a movement towards innovative behavior. This is understood as a process of developing creative ideas and that is capable of fostering new skills.

In this way, the development of aptitudes derives from a high commitment of the professional to exercise the function, considering it important to their occupation (Niemiec \& Ryan, 2012). As the professional visualizes their participation in the work as relevant, there is an engagement of the personal growth that reflects in actions and interactions with other individuals (Abdelmoula \& Boudabbous, 2019).

According to Ntoumanis (2001), Factor 2 (recognition in the professional career) is characterized as an extrinsic motivation, inclined to an introjected regulation, since it consists of behaviors produced with the intent of social recognition. In addition, this regulation presupposes external stimuli so that there is a boost in the choice, which corroborates for an ego involvement since the individual needs an encouragement to persist (Gagné et al., 2010).

Nevertheless, the professional recognition factor converged with the results found in the study by Abdelmoula and Boudabbous (2019), but it is also confirmed that not only is the reward element linked to this factor, but also social recognition, that is, there is a need to instill professional recognition that the teacher feels respected within his interpersonal relationships.

For Factor 3 (contribution to society), we highlight the identified motivation, which is revealed by behaviors aligned with the individual's goals, that is, it is a self-determined form and is manifested by the personal relevance attributed by the individual (Ryan \& Deci, 2000). It is also considered that the identified regulation consists in perceiving the activity performed as something significant, and involves a greater commitment on the part of the professional (Gagné et al., 2010).

Furthermore, Valenzuela et al. (2015) argue that one of the contributions to society linked to the exercise of teaching consists, within the academic space, that this professional is able to develop and develop pedagogical actions that can foster improvements in student learning, and consequently, that he can externalize your knowledge beyond common sense. Thus, as exposed in the study by Davoglio et al. (2017) social contribution is one of the points pointed out by teachers as a significant element in the exercise of teaching performance. This point, in addition to converging with what was found in the present study, also expands the perception of the relevance in enabling these professionals to be able to promote changes in educational processes.

It should be emphasized that the assertive (previous career dissatisfaction), present in Factor 5, denotes amotivation since for Han and Yin (2016) demotivation consists of a negative influence that annuls the existing motivation. In addition, job dissatisfaction ends up causing employee turnover, which directly affects the companies' daily lives. In this sense, it is relevant to understand the concerns of these individuals so that there is no need for them to choose to pursue other activities or even to enter another profession (Daniels \& Davids, 2019). 
In summary, of the six categories established by Ryan and Deci (2000) and among the five assertions found that most explain the termination of the professional career, the predominant motivational components are extrinsic motivation, with emphasis on introjected and identified regulations and demotivation.

\subsection{Factorial Analysis for the Insertion in the Teaching Career and its Permanence}

This topic was composed of 17 assertions adapted from Richardson and Watt $(2005,2007)$, which can identify the reasons for the insertion in the teaching career and some aspects for the permanence in teaching for the 28 respondent teachers. From Table 4 aids the visualization of the values obtained in the Bartlett test as well as in the KMO measurement.

Table 4 - Bartlett Test and KMO

\begin{tabular}{lrr}
\hline Kaiser-Meyer-Olkin & & 0,569 \\
\hline Bartlett's Test of Sphericity & Approximate chi-square & 237,768 \\
\hline & df & 136 \\
\hline & Significance & 0.000 \\
\hline
\end{tabular}

Source: This table shows the values for the KMO and Bartlett's test of sphericity

As shown in Table 4, it is noted that the significance value attributed with the Bartlett test (0.000) can be considered acceptable (Corrar et al., 2017), as well as the obtained KMO value of 0.569 (Corrar et al., 2017; Hair et al., 2009). Thus, the test and measurement's results corroborate in order to make it possible to carry out the factorial analysis for this topic. Accordingly, Table 5 expresses the explanatory power of the assertions, thus demonstrating the values of the variances for each of them.

Table 5 - Total Variance Explained

\begin{tabular}{cccccccccc}
\hline & \multicolumn{3}{c}{ Initial P values } & \multicolumn{3}{c}{$\begin{array}{c}\text { Sum of extraction of square } \\
\text { loads }\end{array}$} & \multicolumn{3}{c}{ Sum of rotations of square } \\
loads
\end{tabular}

Source: Extraction method: principal component analysis 
According to the results shown in Table 5, of the 17 assertions answered, five have an explanatory effect of $74.11 \%$ on the entry and permanence in the career as a teacher. In the meantime, it is also necessary to visualize the adequacy of the data by means of the varimax rotation method, arranged in Table 6.

Table 6 - Component's Rotation Matrix

\begin{tabular}{|c|c|c|c|c|c|}
\hline \multirow[t]{2}{*}{ Assertions } & \multicolumn{5}{|c|}{ Component } \\
\hline & 1 & 2 & 3 & 4 & 5 \\
\hline Teaching provided me with a better career & 0.505 & 0.528 & -0.172 & 0.337 & 0.123 \\
\hline $\begin{array}{l}\text { Teaching provided me with a better economic well-being for } \\
\text { my family }\end{array}$ & 0.505 & 0.575 & -0.293 & 0.327 & 0.110 \\
\hline My family supported my decision & 0.005 & -0.168 & 0.859 & -0.031 & 0.021 \\
\hline $\begin{array}{l}\text { The possibility, by means of a teaching qualification, to } \\
\text { teach in other countries }\end{array}$ & 0.351 & -0.620 & 0.527 & 0.124 & 0.034 \\
\hline Becoming a teacher has increased my social status & -0.033 & 0.207 & 0.086 & 0.795 & 0.243 \\
\hline $\begin{array}{l}\text { Becoming a teacher has increased my level of respect in the } \\
\text { community }\end{array}$ & 0.135 & -0.056 & 0.081 & 0.873 & -0.200 \\
\hline Teaching is an occupation that offers a good salary & 0.033 & 0.845 & 0.049 & 0.271 & 0.007 \\
\hline Teaching allowed me more time with my family & -0.100 & 0.468 & 0.605 & -0.157 & -0.042 \\
\hline $\begin{array}{l}\text { Teaching is an occupation that allows for a more fulfilling } \\
\text { (satisfying) life }\end{array}$ & -0.092 & 0.090 & 0.789 & 0.110 & -0.293 \\
\hline Chances of improving professional skills & 0.753 & -0.038 & -0.246 & 0.429 & -0.026 \\
\hline Teaching offers a stable career & -0.019 & 0.403 & 0.228 & 0.029 & 0.765 \\
\hline Teaching offers a reliable income & 0.068 & 0.867 & 0.155 & -0.190 & 0.047 \\
\hline I identify with the academic career & -0.148 & 0.170 & 0.295 & -0.021 & -0.748 \\
\hline Teaching offers safe work & -0.392 & 0.041 & 0.599 & 0.155 & 0.261 \\
\hline As a teacher I will have more vacation time & 0.489 & -0.244 & -0.136 & 0.398 & 0.274 \\
\hline $\begin{array}{l}\text { Teaching allows me to raise the ambitions of } \\
\text { underprivileged young people }\end{array}$ & 0.895 & 0.053 & 0.069 & -0.160 & 0.002 \\
\hline Teaching allows me to benefit the socially disadvantaged & 0.831 & 0.071 & -0.044 & 0.032 & 0.069 \\
\hline
\end{tabular}

Source: Extraction method: principal component analysis; Rotation Method: Varimax with Kaizer normalization

Table 6 shows the rotation of the components, allowing for the visualization of the variables more clearly in each of the latent factors. They were considered as significant ranging from +0.7 or 0.7, due to the existing high correlation. Thus, one can infer each factor, presented below.

Factor 1: teaching allows me to raise the ambitions of underprivileged young people; chances of improving professional skills. Factor 2: teaching offers a reliable income; teaching is an occupation that offers a good salary. Factor 3: my family supported my decision; teaching is an occupation that allows for a more fulfilling (satisfying) life. Factor 4: becoming a teacher has increased my level of respect in the community; becoming a teacher has increased my social status. Factor 5: teaching offers a stable career; I identify with the academic career (presented negative correlation).

From the results found, we searched for the naming of the factors and understanding of the data obtained. In order to do so, loads with larger values have an influence on the name to be chosen, which are as follows: Factor 1: improving teaching conditions; Factor 2: financial income; Factor 3: family support; Factor 4: social status; Factor 5: career identification.

In relation to the variables belonging to Factor 1 (teaching allows me to raise the ambitions of underprivileged young people and improvement of teaching conditions), intrinsic motivation is perceived as a predominant factor, since it permeates the interest and pleasure of the professional by his or her involvement with the career (Gagné et al., 2010). In addition, this motivation comprises an adaptive behavior: the individual understands the task as a challenge and not in an intimidating way (Bruinsma \& Jansen, 2010). 
Han and Yin (2016) argue that one of the supports of the teaching career involves teaching conditions, that is, the perception of teachers' emotional distress, the high workload and expectations of professional growth. In addition, the perception of improvements in teaching practices is linked to the involvement with the teaching career and that this may impact not only on the lives of students, but also on society in a general sense, from the moment attention returns for improvements in teaching conditions, as well as improvements in educational processes (Klaeijsen et al., 2017).

From the exhibitions by Han and Yin and Klaeijsen et al. (2017) it appears that the findings of the present research converge with what was found. In addition, it also complements by reiterating that the change to the teaching career reinforces the perception of the need for greater attention to accounting professionals who perform other activities not linked to academia.

In Factor 2 (financial income), an emphasis can be seen on the reward element, which evidences, according to Gagné et al. (2010), an extrinsic motivation with an emphasis on external regulation. This regulation consists of the less self-determined form of extrinsic motivation, that is, the individual's behavior is determined due to external contingencies (Deci et al., 1991).

It should also be noted that the reward factor linked to extrinsic motivation denotes one of the most mentioned concerns by Abdelmoula and Boudabbous (2019) when it is inferred about a change in professional activity. This factor makes it necessary to reflect on the need for guidelines to be developed that fairly streamline rewards among employees. In this regard, Han and Yin (2016) ratify that the promotion of financial improvements generates security in the course of work, but they consider that relationships in the professional environment, such as students' attitudes, work facilities, etc. they are still as important pillars to be taken into account when the theme turns to the insertion of professionals in the teaching career.

Among the variables arranged in factors 3 (family support) and 4 (social status), there was a predominance of extrinsic motivation, with an emphasis on introjected regulation, which expresses behaviors that are not self-determined in their totality; that is, the presence of this motivation occurs when the professional relates the career entry with a possible social recognition (Ntoumanis, 2001). As the career choice permeates contingency actions, such as self-esteem, it gradually becomes internalized behavior and one has introjected motivation (Han \& Yin, 2016).

Davoglio et al. (2017) reiterate that in addition to the behavioral aspects that imply the option for the teaching career, the organizational structure also receives attention, that is, there is a need for this professional not only to choose, but also to remain in the teaching career of subsidies that foster professional growth, such as, for example, continuing education. This allows teachers to improve both skills and, consequently, can generate improvements in educational processes.

Regarding factor 5 (career identification), this presented as the main motivation, the identified regulation, and refers to an alignment between the professional and the activities that he or she wishes to participate. The result of the behavior is perceived as something to be done without imposition, even if the situation is not considered as agreeable; for example, a teacher participating in an activity that improves some of their abilities (Ntoumanis, 2001).

For Araújo et al. (2015) one of the identification points with the teaching career touches not only stability, but also the possibility of the development of that career. This does not correspond to a triggering of events, but to a continuum of processes. In addition, another point that deserves to be highlighted is that the teacher, when realizing that his actions of teaching and learning are reflecting in the way the students deal with different situations (daily personal and / or professional) can signal recognition by the student. teacher of the existence of meaning by the choice of teaching career.

It should be emphasized that the variable (I identify with the academic career) presented a negative correlation, which symbolizes that the insertion in the teaching career is not fully aligned with the identification with the profession itself, which corroborates that there are entries into the teaching career by virtue of other elements, such as family imposition, remuneration, security in public employment, etc. In summary, the predominant motivations, according to the respondents and the analyses carried out were the following: external, introjected and intrinsic. 


\section{FINAL CONSIDERATIONS}

The aim of this research was to investigate the predominant motivational factors for the transition of business accounting professionals to a teaching career as an Accounting Sciences professor at Brazilian Federal Universities.

Given the motivational taxonomy developed by Ryan and Deci (2000), the analysis described the predominant motivations for the termination of the professional career before entering the teaching career is composed by extrinsic motivation pertaining to the introjected and identified regulations, as well as demotivation, as one of the main factors. In addition, the motivational elements inserted in the introjected and identified regulations are adjacent - that is, they function in a complementary way.

Thus, there are motivational elements known as pro-social, which are expressed through introjected and identified regulations, which lead professionals to a state of persistence through goals. Meanwhile, after the insertion in teaching the inherent motivational components are expressed by the motivations of introjected and external regulation, as well as the presence of intrinsic motivation.

In this way, the results found corroborate with the study by Davoglio et al. (2017), since even in the existence of intrinsic elements in the continuity of the teaching career, the interaction with the external motivation represented by the remuneration variable is considerable, being one of the assumptions for entry and permanence in the teaching career. In addition, observance of the extrinsic and intrinsic motivations found in the teaching career makes reference to behaviors considered nondichotomous among the motivational components.

In summary, the motivational elements are not presented in a sequential way - that is, they do not necessarily need to be continuously disposed of demotivation, extrinsic and intrinsic motivations, consistent with the understanding proposed by Deci et al. (1991). The corroboration is given by the answers found, for it was identified not only one motivation in each topic but also some motivations which were perceived as the most relevant for teachers. It ratifies the positioning of Han and Yin (2016), for the factors that strongly influence the maintenance of the motivation of teachers throughout their careers.

Thus, based on the answers obtained, some theoretical and practical contributions inherent to the study can be listed. Regarding the theoretical contribution, it is mentioned that the breadth that the study allowed to identify the predominant factors not only in the disconnection from the professional career in a private company and / or autonomously, but also the factors that make the Accountant (a) seek insertion in the academic area. In this sense, the study expands some perceptions, such as, for example, the need for more research to aim at discussions that can express the concerns and dissatisfactions of these teachers so that strategies and / or actions that can mitigate their discontent may arise.

From the practical point of view, the perception of a scenario that involves not only stability as a contribution to career exit and insertion in teaching at federal public universities is a contributing factor, but also the chance of these professionals to effectively corroborate with its students, and therefore with society. However, for the existence of such collaborative movements between teachers and students, it is necessary that the training aspect of these professionals be taken into account. Thus, mention is made of the need for teacher improvement to be perceived as something relevant to society and that can consistently impact improvements in educational processes, as well as and especially in students' lives.

The results obtained can be considered satisfactory in relation to the established objective, since they aid in the perception of what leads an accounting professional, in face of several possibilities of work, to choose and remain in the teaching career. In summary, the predominance of the answers, with respect to the open question, emphasizes the financial stability provided by the public service at the beginning of the career, in line with the pleasure of teaching. At the same time, 
the withdrawal of business activity is due, among other factors, to the lack of motivation in the development of this activity.

Thus, one of the study's limitations was the lack of relation of the motivational factors that involve the professionals of the private universities, since the non-requirement of exclusive dedication in these institutions may bring new contours on the decisions made by these professionals, as well as their expectations regarding the labor market and their future aspirations. Another limiting point was the non-use of a database that contained the observable (demographic) characteristics of the professors who did not participate in the research for the possibility of a comparison between the samples (respondents and non-respondents). Such limitations may be pointed out as suggestions for further studies in this area.

\section{REFERENCES}

Abdelmoula, L. \& Boudabbous, S. (2019). Drivers of the Professional Accountants' Satisfaction in Tunisian Context. International Journal of Academic Research in Accounting, Finance and Management Sciences, 9(2), 183-197.

Amabile, T. M. (1993). Motivational synergy: Toward new conceptualizations of intrinsic and extrinsic motivation in the workplace. Human resource management review, 3(3), 185-201.

Amabile, T. M., Hill, K. G., Hennessey, B. A. \& Tighe, E. M. (1994). The Work Preference Inventory: assessing intrinsic and extrinsic motivational orientations. Journal of personality and social psychology, 66(5), 950.

Araújo, T. S., Lima, F. D. C., Oliveira, A. C. L. D., \& Miranda, G. J. (2015). Perceived Problems of Being an Accounting Teacher. Revista Contabilidade \& Finanças, 26(67), 93-105.

Brasil. Ministério da Educação (2018). Instituições de Ensino Superior credenciadas pelo MEC. Recuperado em http://emec.mec.gov.br.

Bruinsma, M. \& Jansen, E. P. (2010). Is the motivation to become a teacher related to pre-service teachers' intentions to remain in the profession? European Journal of Teacher Education, 33(2), 185-200.

Coordenação de Aperfeiçoamento de Pessoal de Nível Superior (2018). Portal de periódicos. Recuperado de http://www.capes.gov.br.

Corrar, L., Paulo, E., Dias Filho, J. M. \& Rodrigues, A. (2017). Análise multivariada para os cursos de administração, ciências contábeis e economia. São Paulo: Atlas.

Daniels, N. \& Davids, R. (2019). Retaining newly qualified chartered accountants: A South African case study. South African Journal of Accounting Research, 33(3), 220-235.

Davoglio, T. R., Spagnolo, C. \& Santos, B. S. D. (2017). Motivação para a permanência na profissão: a percepção dos docentes universitários. Psicologia Escolar e Educacional, 21(2), 175-182.

Deci, E. L., Vallerand, R. J., Pelletier, L. G. \& Ryan, R. M. (1991). Motivation and education: The selfdetermination perspective. Educational psychologist, 26(3-4), 325-346.

Felton, S., Dimnik, T. \& Northey, M. (1995). A theory of reasoned action model of the chartered accountant career choice. Journal of Accounting Education, 13(1), 1-19.

Fonseca, R. A., Taroco, J. S., Nazareth, L. G. C. \& Ferreira, R. D. N. (2014). A Importância do Contador nas Organizações. Anais do SEGeT Simpósio de Excelência em Gestão e Tecnologia, Resende, RJ, Brasil, 11.

Gagné, M., Forest, J., Gilbert, M. H., Aubé, C., Morin, E. \& Malorni, A. (2010). The Motivation at Work Scale: Validation evidence in two languages. Educational and psychological measurement, 70(4), 628646.

Han, J. \& Yin, H. (2016). Teacher motivation: Definition, research development and implications for teachers. Cogent Education, 3(1), 1-18. 
Hair, J. F., Black, W. C., Babin, B. J., Anderson, R. E. \& Tatham, R. L. (2009). Análise multivariada de dados. São Paulo: Bookman.

Hoogenboom, B. J. \& Manske, R. C. (2012). How to write a scientific article. International journal of sports physical therapy, 7(5), 512.

Kiz1ltepe, Z. (2008). Motivation and demotivation of university teachers. Teachers and Teaching, 14(5-6), 515-530.

Klaeijsen, A., Vermeulen, M. \& Martens, R. (2017). Teachers' innovative behaviour: The importance of basic psychological need satisfaction, intrinsic motivation, and occupational self-efficacy. Scandinavian Journal of Educational Research, 62(5), 769-782.

Law, P. K. (2010). A theory of reasoned action model of accounting students' career choice in public accounting practices in the post-Enron. Journal of Applied Accounting Research, 11(1), 58-73.

Lehman, G. (2001). Reclaiming the public sphere: problems and prospects for corporate social and environmental accounting. Critical Perspectives on Accounting, 12(6), 713-733.

Markland, D. \& Tobin, V. (2004). A modification to the behavioural regulation in exercise questionnaire to include an assessment of amotivation. Journal of Sport and Exercise Psychology, 26(2), 191-196.

Miranda, G. J., Leal, E. A. \& Medeiros, C. R. (2010). Interdisciplinaridade no curso de Ciências Contábeis: os desafios e as possibilidades de aprender e ensinar a partir de uma experiência. Revista de Educação e Pesquisa em Contabilidade (REPeC), 4(3), 1-22.

Myburgh, J. E. (2005). An empirical analysis of career choice factors that influence first-year accounting students at the University of Pretoria: a cross-racial study. Meditari Accountancy Research, 13(2), 35-48.

Nadim, M., Chaudhry, M. S., Kalyar, M. N. \& Riaz, T. (2012). Effects of motivational factors on teachers' job satisfaction: a study on public sector degree colleges of Punjab, Pakistan. The Journal of Commerce, 4(4), 25.

Niemiec, C. P. \& Ryan, R. M. (2009). Autonomy, competence, and relatedness in the classroom: Applying self-determination theory to educational practice. School Field, 7(2), 133-144.

Ntoumanis, N. (2001). A self-determination approach to the understanding of motivation in physical education. British journal of educational psychology, 71(2), 225-242.

Pelletier, L. G., Tuson, K. M., Fortier, M. S., Vallerand, R. J., Briere, N. M. \& Blais, M. R. (1995). Toward a new measure of intrinsic motivation, extrinsic motivation, and amotivation in sports: The Sport Motivation Scale (SMS). Journal of sport and Exercise Psychology, 17(1), 35-53.

Richardson, P. W. \& Watt, H. M. (2005). 'I've decided to become a teacher': Influences on career change. Teaching and teacher education, 21(5), 475-489.

Ribeiro Filho, J. F. (2010). Revista de Educação e Pesquisa em Contabilidade. Recuperado em https://scholar.google.com.br/scholar.

Ryan, R. M. \& Deci, E. L. (2000). Intrinsic and extrinsic motivations: Classic definitions and new directions. Contemporary educational psychology, 25(1), 54-67.

Roberts, J. (1991). The possibilities of accountability. Accounting, organizations and society, 16(4), 355-368.

Sakamoto, C. K. \& Silveira, I. O. (2019). Como fazer projetos de Iniciação Científica. Pia Sociedade de São Paulo: Paulus.

Schmutte, J. (1998). Student and public accounting firm recruiter attitudes toward the desirability of student characteristics: a longitudinal study. Journal of Accounting Education, 16(3-4), 429-461.

Sistema Integrado de Bibliotecas Universidade de São Paulo (2018). Portal de periódicos. Recuperado em http://www.sibi.usp.br.

Silva, G. V. (2016). Motivação para o trabalho docente. Jundiaí: Paco Editorial. 
FROM ACCOUNTING PROFESSIONAL TO TEACHING CAREER: A STUDY ON THE MOTIVATIONAL

FACTORS FOR THE TRANSITION

Tuckman, B. W. (1974). An age-graded model for career development education. Journal of vocational Behavior, 4(2), 193-212.

Valenzuela, J., Valenzuela, C. M., Silva-Peña, I., Nocetti, V. G., \& Gandarillas, A. P. (2015). Motivación escolar: Claves para la formación motivacional de futuros docentes. Estudios pedagógicos (Valdivia), 41(1), 351-361.

Vallerand, R. J. \& Blssonnette, R. (1992). Intrinsic, extrinsic, and amotivational styles as predictors of behavior: A prospective study. Journal of personality, 60(3), 599-620.

Watt, H. M. \& Richardson, P. W. (2007). Motivational factors influencing teaching as a career choice: Development and validation of the FIT-Choice scale. The Journal of experimental education, 75(3), 167-202. 